\title{
ESSENCE, CONTENT AND IMPORTANCE OF STRATEGIC MANAGEMENT
}

\author{
Marioara TULPAN, Cristina SUCIU \\ Industrial Engineering, University of Petrosani, Romania \\ e-mail: maryat1977@yahoo.com; cristina_suciu27@yahoo.com
}

\begin{abstract}
From a historical point of view, it can be said that at the level of the enterprises, especially the profitable ones, there has always been a strategic thinking even if it was a strategy lacking in formalism that did not rely on the methods of analysis and did not have a wide communication. The growing business development, the high absorption capacity of the market, the low cost of energy and the labour force, the accelerated pace of technical progress represented all the phenomena that made the need for strategies to be less prominent.
\end{abstract}

KEYWORDS: strategic, management, enterprises, economic

\section{Introduction}

Even though the strategic management statement has made its official entrance to theoretical language since 1973, at The First International Conference of Strategic Management, organized by I.H. Ansoff at Vanderbilt University. The idea given to this concept by authors are generally quite different, the strategic management being considered as:

- the process that aims to facilitate the leadership of an organization and uses the strategy to guide its actions, integrates the commissioning of strategic actions related to structural and cultural factors;

- the form of leadership that seeks to ensure the best possible relationship between the demands of the environment, the internal and external partners and the objectives of the leaders, in time to be interested both in the interior and the outside of the enterprise, in the economic, organizational dimension;

- a set of decisions and actions that lead to the development of an effective strategy to help meet corporate goals;
- the process through which the company's management establishes the organization's long-term directions and results, ensuring a slow formulation, proper implementation and ongoing evaluation of the strategy.

The diversity of conceptual definitions used by authors sometimes means not only differences in language but also in substance, depending on the different perception of the phenomena and the scope of each of them to the strategic management, the changes that took place in the plan of strategic thinking and conceptions about the organization.

Strategic management is a complex process of prefiguring its future, its long-term evolution, process in which its strategy formulation, implementation, evaluation and permanent control are combined and complement each other in a continuous, dynamic flow. So strategic management is not a process of formulating the strategy that overlaps the enterprise management system, but a new form of strategybased management.

\section{Strategic management features}

Table. 1. The three dimensions of strategic management

\begin{tabular}{|c|c|c|}
\hline $\begin{array}{l}\text { The rational and analytical } \\
\text { process (economic dimension) }\end{array}$ & $\begin{array}{c}\text { The socio-political process (human } \\
\text { dimension) }\end{array}$ & $\begin{array}{l}\text { The bureaucratic process } \\
\text { (organizational dimension) }\end{array}$ \\
\hline $\begin{array}{c}\text { What does he wants? } \\
\text { - defining strategic areas of activity } \\
\text { - mission statement } \\
\text { - fix the targets } \\
\text {-choosing the portfolio of activities }\end{array}$ & $\begin{array}{c}\text { Who are the "actors"? } \\
\text { - identifying " actors " } \\
\text { - dynamic analysis of the link } \\
\text { between the enterprise and " actors" } \\
\text { - looking for a political base and } \\
\text { assessing the opposition }\end{array}$ & $\begin{array}{c}\text { What kind of organization is it? } \\
\text { - choosing the degree of decentralization } \\
\text { - determining the size of operational } \\
\text { units } \\
\text { - division of labour } \\
\text { - choosing the means of coordination }\end{array}$ \\
\hline
\end{tabular}




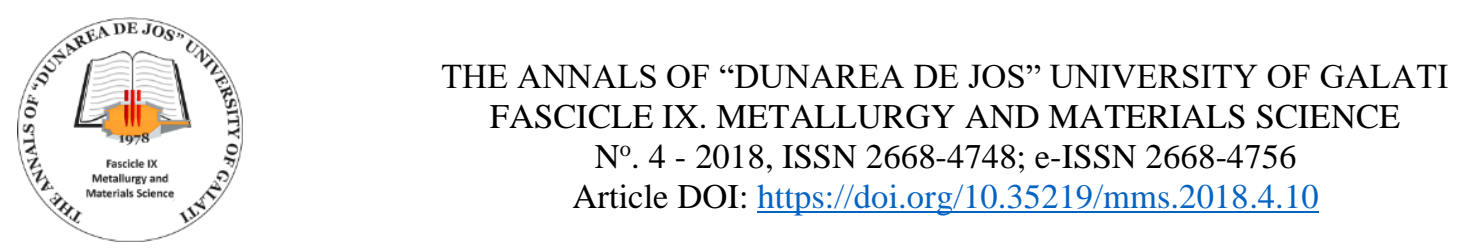

\begin{tabular}{|c|c|c|}
\hline & & - developing the international system \\
\hline $\begin{array}{c}\text { Who are we? What is the situation? } \\
\text { - environmental analysis } \\
\text { - evaluation of resources } \\
\text { - determining the planning }\end{array}$ & $\begin{array}{c}\text { What can 'actors' do? } \\
\text { - analysis of internal and external } \\
\text { political influences } \\
\text { - evaluating the 'actors' political } \\
\text { system } \\
\text { - anticipating the reaction of "actors" }\end{array}$ & $\begin{array}{l}\text { Which decision-making process? } \\
\text { - choosing the type of plan } \\
\text { - determining the incremental steps } \\
\text { - choosing the horizon } \\
\text { - explaining the content of the plans } \\
\text { - developing the decision-making } \\
\text { process }\end{array}$ \\
\hline $\begin{array}{c}\text { What does he want to do? } \\
\text { - formulation of strategies and } \\
\text { policies } \\
\text { - evaluating strategies and policies }\end{array}$ & $\begin{array}{l}\text { What can be done with or against } \\
\text { "actors"? } \\
\text { - searching for 'actors' independence } \\
\text { - select alliances and correlations }\end{array}$ & $\begin{array}{c}\text { What animation style? } \\
\text { - determining the level of participation } \\
\text { - developing an evaluation and reward } \\
\text { system } \\
\text { - choosing the degree of freedom of } \\
\text { operations } \\
\text { - setting the intensity of each person's } \\
\text { tracking and tracking }\end{array}$ \\
\hline $\begin{array}{c}\text { What will he do? } \\
\text { - choice of strategy } \\
\text { - setting up programs, action plan } \\
\text { and budget } \\
\text { - looking for an adapted } \\
\text { management system }\end{array}$ & $\begin{array}{l}\text { What does he decide to do? } \\
\text { - formulation of political strategy } \\
\text { - anticipating the reactions of the } \\
\text { opponents }\end{array}$ & $\begin{array}{c}\text { Which control procedures? } \\
\text { - choosing the concentration of control } \\
\text { - determining the frequency and level of } \\
\text { control } \\
\text { - selecting the detail of the control } \\
\text { - search for control orientation }\end{array}$ \\
\hline
\end{tabular}

\section{Similarities and differences between strategic management and strategic planning}

Although similar, the terms of strategic planning and strategic management are not synonyms, and their scope is different.

- while strategic planning describes the periodic activities undertaken by the enterprise to cope with changes in its environment and has a sequential nature, an unforeseen event occurring outside a phase of strategic reflection being taken into account only in the next phase, strategic management is a continuous process, dynamic updating and permanent adaptation of strategic decisions according to the various important elements that appear along the way;

- if strategic planning is limited to business relationships with the environment, strategic management has in its internal structure and decisions, the development of skills and competencies capable of giving the enterprise the flexibility necessary to new situations, to ensure its efficient operation and optimal integration into the environment from which is part of it;

- unlike strategic planning, which involves formulating and evaluating strategic alternatives, choosing the strategy and drawing up detailed plans for its implementation, strategic management includes strategic control, which is to ensure that the chosen strategy is properly implemented and brings the desired results, respectively in analysing differences and making the necessary changes when they occur;
- if the strategic planning process is a plan that can leave unchanged the culture of the enterprise, the organization, the behaviour, the strategic management consists of a series of decisions, strategies and actions, in a new strategic behaviour that involves the transformation of the organization itself in view of its depreciation the external environment.

From the perspective of what has been said, it is clear that the strategic management has a richer content and a broader scope than the strategic planning which, in fact, includes it as a tool of realization. It consists of a set of decisions and actions that result in the formulation, implementation and control of the adopted strategies, in order to achieve the organization's objectives and its profitable adaptation to the changes of the environment.

\section{Strategic typologies in the competitive economy}

The analysis of the theory and practice of the contemporary market economy highlights an appreciable typological variety of strategies that actually outlines the way companies can deliver their mission and adapt to change. Of course, in terms of enterprise strategy, it is hard to appreciate and we do not believe it can be guaranteed that the application of one or the other will automatically lead to the success of a company, given the multitude of influence factors, ranging from the specifics of the enterprises to the particular characteristics of the environment in which each operates. 


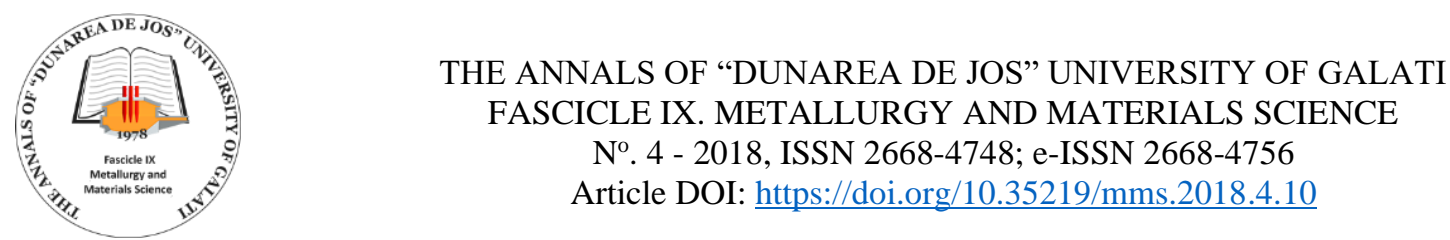

Table 2. Types of strategies

\begin{tabular}{|c|c|c|}
\hline Level of goal hierarchy & Overall (of the corporation) & $\begin{array}{l}\text { More general. It focuses on the business } \\
\text { portfolio and the allocation of resources } \\
\text { between different businesses }\end{array}$ \\
\hline & Business & $\begin{array}{l}\text { focuses on how to compete in a business, } \\
\text { highlighting the competitive advantage } \\
\text { that the company has in relation to } \\
\text { competitors. Targets average horizons of } \\
1-3 \text { years. }\end{array}$ \\
\hline & Functional & $\begin{array}{l}\text { are more specific than business strategies. } \\
\text { Target short time horizons } 1 \text { year or less. }\end{array}$ \\
\hline \multirow{3}{*}{ Time horizon } & Long-term & $\begin{array}{l}\text { refers to the evolution of firms for periods } \\
\text { of } 10,15 \text { or } 20 \text { years. }\end{array}$ \\
\hline & In the medium term & target small periods of time \\
\hline & Short term & $\begin{array}{l}\text { typically, small firms focused on } \\
\text { immediate results }\end{array}$ \\
\hline \multirow{2}{*}{$\begin{array}{l}\text { The degree of participation } \\
\text { of the firm in the } \\
\text { development of the strategy }\end{array}$} & full & $\begin{array}{l}\text { the characteristics of the state-owned } \\
\text { enterprises are elaborated by their } \\
\text { management together with the menus of } \\
\text { the supersystem they belong to. }\end{array}$ \\
\hline & independent & $\begin{array}{l}\text { defining for private companies. focus on } \\
\text { maximizing profits, strengthening market } \\
\text { position and ensuring survival }\end{array}$ \\
\hline \multirow{3}{*}{$\begin{array}{c}\text { The dynamics of the main } \\
\text { objectives }\end{array}$} & $\begin{array}{l}\text { offensive (growth or } \\
\text { development) }\end{array}$ & $\begin{array}{c}\text { aim to increase the volume of sales, } \\
\text { revenues and profits, increase the activity } \\
\text { of the company by achieving a large } \\
\text { quantity of goods or services }\end{array}$ \\
\hline & setting, maintaining & $\begin{array}{l}\text { maintaining the current business situation } \\
\text { is considered satisfactory. The increase is } \\
\text { possible but slow and unpromising }\end{array}$ \\
\hline & defensive & $\begin{array}{l}\text { the main purpose: survival, cost reduction, } \\
\text { elimination of losses }\end{array}$ \\
\hline
\end{tabular}

\section{Conclusions}

Beyond other factors, effective implementation of the strategy and performance of an enterprise depends to a large extent on the quality of the personnel and its identification with the purpose and objectives of the organization. As managerial and human relations representatives say (McGregor's Y theory, for example), people assume their responsibilities and participate in the work process to the extent that they are motivated and stimulated in their actions. Taking into account the complexity of human nature, motivation is an essential concept in psychology, expressing the fact that the basis of the human condition is always a set of needs, tendencies, intentions, ideals that support the realization of certain actions, deeds and attitudes.

Assuming the permanent adaptation of the enterprise to the environment in which it operates, strategic management involves the transformation of the enterprise in time. This means that any transformation produced in one of the components of the strategic management model may require changes in any or all of the other components, the strategic management representing a permanent process of updates and re-evaluations, within which the strategy formulation, implementation and evaluation are merged and complement each other in a continuous flow. The strategy must therefore be approached not as a rigid projection of the future of the enterprise but as a flexible process of adaptation and re-adaptation to changes in dimensional parameters or of the enterprise and its environment so as to permanently reflect the mutations in the competition perimeter but also the broader (economic, social, cultural) national and international environment.

The printing of this behavioural trait, specific to the market economy, consists of a scientific adaptation of the strategy, which implies both a thorough knowledge and mastery of the concepts and techniques of strategic management, as well as the amplification of the foreseeable, prospective dimension of the management, without which cannot be achieved a strategic projection able to provide an adequate response to the major challenges of transition and the world economy. 


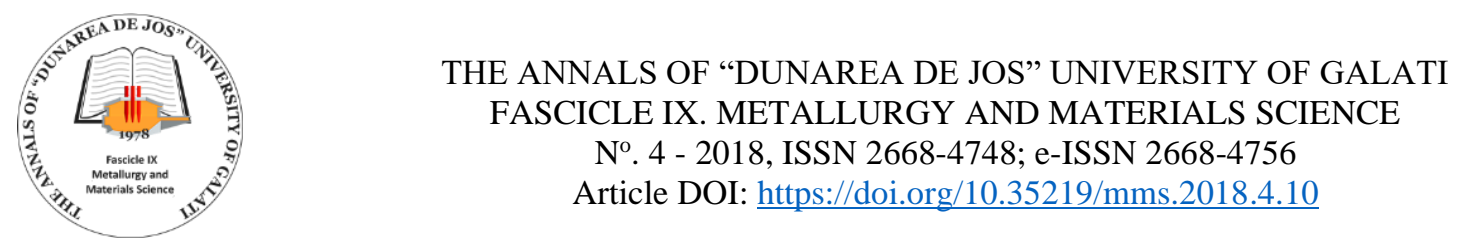

\section{References}

[1]. Abrudan I., Premises and landmarks of Romanian managerial culture, Dacia Publishing House, Cluj-Napoca, 1999.

[2]. Abrudan I., et al., Economic Engineering Manual. Production Systems Engineering, Dacia Publishing House, Cluj-Napoca, 2002. [3]. Abrudan I., et al., SMEs and their specific management, Dacia Publishing House, Cluj-Napoca,

[4]. Abrudan I., At the gates of Europe. A vision on the European integration of Romania, Management and Economic Engineering Magazine, vol. 5, no. 4(20), p. 5, Cluj-Napoca, 2006.

[5]. Abrudan I., Time Factor Management, Management and Economic Engineering Magazine, vol. 5, no. 3, Cluj-Napoca, 2006. [6]. Abrudan I., Leibnitz's triumph of Leibnitz's "sufficient reasoning principle" or 10 years since the founding of the Consortium of Economic Engineering in Romania, Management and Economic Engineering Magazine, vol. 5, no. 2(18), p. 5, ClujNapoca, 2006
[7]. Baron T., Statistical methods for analysis and quality control of production, Didactic and Educational Publishing House, Bucharest, 1979.

[8]. Baron T., et al., Quality and Reliability, Technical Publishing House, Bucharest, 1988.

[9]. Baron T., Theoretical and Economic Statistics, Didactic and Educational Publishing House, Bucharest, 1996.

[10]. Bălan G., Tîtu M., Bucur V., The Management of Change and The Competition Advantage, $10^{\text {th }}$ International Research / Expert Conference "Trends in the Development of Machinery and Associated Technology", TMT 2006, p. 497-500, Barcelo-Lioret de Mar, Spain, 11-15 September, 2006.

[11]. Cănănău N., Dima O., Gură Gh., Barajas Gonzales Ana, Quality Assurance Systems, Junimea Publishing House, Iaşi, 1998.

[12]. Cicală E., Methods of Statistical Processing of Experimental Data, Polytechnic Publishing House, Timişoara, 1999.

[13]. Ciobanu I., Strategic Management, Polirom Publishing House, Iaşi, 1998. 